\title{
The effect of stakeholder's commitment and government regulations on dry port firm performance
}

\author{
Engkos Achmad Kuncoro ${ }^{a}$, Dicky Hida Syahcharia ${ }^{*}$, Hardijanto Saroso ${ }^{a}$, Darjat Sudrajat ${ }^{a}$ and Henny \\ K.W. Jordaan ${ }^{b}$
}

${ }^{a}$ Management Department, BINUS Business School Undergraduate Program, Universitas Bina Nusantara, Jakarta, Indonesia ${ }^{b}$ Research Group for Logistics and Alliances Hogeschool Arnhem and Nijmegen, Arnhem, Netherlands

\section{H R O N I C L E}

Article history:

Received: February 27, 2021

Received in revised format:

April 292021

Accepted: May 21, 2021

Available online:

May 21, 2021

Keywords:

Cikarang Dry Port

Government regulation

Stakeholder Commitment

\section{A B S T R A C T}

The dry port (or land port) is an inland area or an intermodal port directly connected to a seaport. Cikarang Dry Port, as one of the best performing dry ports among other dry ports in Indonesia, only contributes $18 \%$ of the loading and unloading volume at Tanjung Priok port. This study examines the effect of supply chain collaboration and service stakeholder engagement on Dry Port Company's performance. The data collected from a questionnaire. The 55 responses from employees of Cikarang dry port and a logistics company in Jakarta. The hypothesis was tested by multiple regression. This study confirms that government regulation and Stakeholder Commitment positively impact the performance of port companies. The study inspires managers to recognize the positive results of government regulation practice among stakeholder engagement organizations to improve port performance in port supply chains.

\section{Introduction}

Every product that the company produces requires logistical activities from the factory to the final buyer. In this regard, does the amount of logistics costs in Indonesia support the import and export movement? Or too high logistics costs make Indonesia unable to face global competition experiencing dimensional changes and rapid movements (Kennedy, 2019). National competitiveness is no longer determined by the company's internal factors but by the country's prevailing logistics system. In terms of increasing the competitiveness of primary commodities, several inhibiting factors are high logistics costs, unfavorable business environment, low quality of transportation and communication infrastructure, unfavorable international trade regulations, investment and customs, poor enforcement of the law, non-tariff barriers to trade in goods and services (Lantu et al., 2016). These obstacles have a significant impact on the global competitiveness of all Indonesian companies. One of Indonesia's global competitiveness in terms of logistics is the problem of logistics costs. The government's priority to reduce national logistics costs is to reduce the dwell time, which is the time calculated from the time when imported cargo containers unloaded from the means of transport to the exit of the merchandise port. Indonesia's dwell time is still around 3-4 days and is the ASEAN's slowest residence time (Kamil et al., 2020). One of the government's strategies to reduce the residence time is by optimizing the dry ports, the container land terminal as the "extended door" of the seaports, where the issuance of imported containers can be carried out. It is directly without customs in advance in a port, but it is finished in a dry port, so the shipping process can also be faster and easier. The government itself hopes that the dry port operation can reduce the residence time to 2 (two) days. However, this condition has not materialized as expected due to various factors. Cikarang dry port, as one of the best performing dry ports among other dry ports in Indonesia, only contributed $18 \%$ of the loading and unloading volume

* Corresponding author

E-mail address: dicky.syahchari@binus.edu (D. H. Syahchari)

(C) 2021 by the authors; licensee Growing Science, Canada doi: $10.5267 /$ j.ac. 2021.5 .014 
at Tanjung Priok port, still far from the initial expectation of 60\% (Yulianti et al., 2020). Factors that affect land ports' performance are good road access to land and rail terminals to increase transhipment volume and cargo traffic growth (Witte et al., 2015). Correct and appropriate government policies can affect the performance of a dry port company to increase or decrease. Government intervention in the economy is carrying to increase public spending. The government's role in improving logistics companies' performance must receive responses from various parties (Novar et al., 2018). The traditional view holds that government regulation is a burden, a cost, a limitation for the logistics business. Also, the impact of the rule will affect the performance of the company. Still, it is erroneous in terms of the agents' perception of the regularity's regulatory effects or duration between regulations and performance indicators. Stakeholders (interested parties) are organizations, groups, and individuals who can influence or be influenced by their activities (Grigoriou \& Rothaermel, 2017). Based on the above explanation, the objective of this study is to examine the impact of government regulation and stakeholder engagement on the performance of Dry Port Company.

\section{Literature review and hypothesis development}

\subsection{The Dry Port Company Performance}

The dry port (or land port) is an inland area or an intermodal port directly connected to a seaport. This area allows the operator to pick up or drop off the load now at the intermodal station. The port dry port services with the same level of service as the port are storage, maintenance, and cleaning containers and customs. This dry port can help expand essential areas around the harbour (Witte et al., 2019). The World Bank developed a standard for measuring port performance, the Logistics Performance Index (LPI). The port's LPI is a macroeconomic indicator that is used to help combine data into standard hands. The LPI is evaluated based on six main criteria: (1) efficiency of the licensing process (2) quality of infrastructure related to trade and transportation; (3) ease of organizing shipments at competitive prices; (4) competence and quality of logistics services; (5) the ability to track and trace shipments; (6) timeliness of delivery to the destination according to the scheduled or expected delivery time (Rezaei et al., 2018).

\subsection{A relationship is between government regulation and dry port company performance}

Regulations are generally necessary due to information inequality, market failure, and government failure. Logistics regulations are all government regulations that regulate logistics activities in the form of rules, laws, decrees, stipulations, and guidelines. These regulations cover the fields of transport, customs, export-import, storage, ports, logistics systems, logistics services, and other technical laws (Dube et al., 2016). Logistics regulation is the process of planning, facilitating, implementing, monitoring, and controlling the flow and storage of goods within and between the logistics systems that companies use, agents, governments, or organizations to increase the competitive advantage in efficiency and justice (Simatupang \& Sridharan, 2018). In the form of customs, the government, tariffs, and fees are additional considerations in determining the company's performance and regulations and provisions on transfer pricing. For large global companies with production facilities in many different countries and with distributed distribution centers and multiple markets, supply chain decisions can significantly affect the total tax bill (Giao et al., 2020). Government regulations that are important in logistics activities include export-import regulations, internal regulations (land, sea, rail, air, multimodal transport) and tax regulations. Based on the previous arguments, it can be stated that Hypothesis 1 (H1) There is a positive and significant relationship between government regulations and the dry port company's performance. Stakeholder engagement relationships and company performance

\subsection{The relationship is between stakeholder commitment and dry port company}

Stakeholders (interested parties) are organizations, groups, and individuals who can influence or be influenced by their activities (Grigoriou \& Rothaermel, 2017). Stakeholders have personal interests or claims in the performance and survival of the business. Stakeholders can be grouped based on whether they are internal or external to the company. Internal stakeholders include shareholders, employees (including executives, managers, and workers), and board members. External stakeholders include customers, suppliers, alliance partners, creditors, unions, communities, governments at various levels, and the media. According to Hitt et al. (2016), stakeholders can be group into capital markets, market products, and organizational. All stakeholders make specific contributions to the company, which provides different types of benefits for various stakeholders. Employees donate their time and talents to the company, receiving wages and salaries in return. Shareholders bring in the capital, hoping that the stock will rise and the company will pay dividends. Communities provide real estate, infrastructure, and public safety. In return, they expect the company to pay taxes, create jobs, and not pollute the environment. Therefore, companies are embedded in a multifaceted exchange relationship with several diverse internal and external stakeholders (Hitt et al., 2016). Effective stakeholder management can benefit company performance (Grigoriou \& Rothaermel, 2017). Satisfied stakeholders are more cooperative and more likely to disclose information to increase business value creation or reduce costs and gain greater trust. Effectively managing a complex network of stakeholders can lead to greater organizational adaptability and flexibility for more predictable and stable returns. Companies can build a solid reputation appreciated in the marketplace by business partners, employees, and customers. In supply chain management, various stakeholders (stakeholders) must 
commit to three fundamental aspects, namely service (Level of service), cost (cost), and cash (working capital). In terms of service (Level of service), stakeholders must commit to how the collaboration can provide the level of service expected by customers, so giving comprehensive facilities and services and flexibility in operations is significant. In the meantime, in terms of costs, stakeholders must commit to the efficiencies that their trading partners can afford, including operating expenses, research and development, sales, and depreciation or amortization. Also, stakeholders in the supply chain must be committed to the cash capacities (working capital) of the partners involved to meet all payment obligations that arise as a result of the collaboration. In the context of the dry port business supply chain, the service engagement is a stakeholder engagement to provide or use the facilities or services required or provided by the dry port business. The cost commitment is the interested parties' commitment to rationalizing the dry ports company's operating costs to offer competitive prices to its customers. Meanwhile, the cash commitment is the stakeholder's commitment to optimize the dry port company's cash flow to finance its operations. Stakeholders in dry port logistics activities include port operators, train operators, customs, land transport companies, logistics or freight forwarders, warehousing companies, and customers (Lamii et al., 2020; HervásPeralta et al., 2019; Khaslavskaya \& Roso, 2020). Based on the arguments raised, it can state that Hypothesis 2 (H2) There is a positive and significant relationship between the Service Stakeholder Commitment and Dry port Firm Performance.

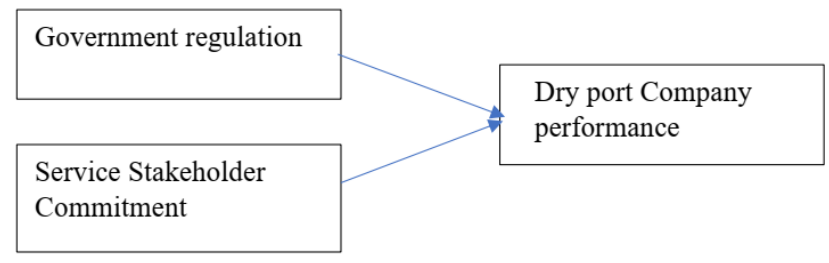

Fig. 1. Research framework

\section{Research Methodology}

The population in this study were Dry Port Cikarang employees and partners of up to 75 respondents. The sampling technique used random sampling techniques, namely, random sampling. The questions in the attached questionnaire are asked on a Likert scale from 1 to 5 . The Likert scale is generally used in Indonesia to measure attitudes, opinions, and perceptions. Considering several hypothetical associations with their interrelated constructs, we use multiple regression to test our model. We began to evaluate the measurement model, validity, and reliability. Final test our hypothesis using SPSS software. We use multiple regression to test the model. The independent variable predicts the dependent variable. In this study, the independent variable is Government regulation, Service Stakeholder Commitment, while the dependent variable is Dry port Company performance

\section{Data analysis}

\subsection{Descriptive Statistics}

Fig. 2 summarizes the survey respondents' characteristics in terms of seniority, Length of work, and education level. The respondents of Level of seniority were Director 3\%, Senior Manager 9\%, Manager 17\%, Supervisor 26\%, Staff 45\%; Length of work were $1-5$ years $40 \%, 6-10$ years 55\%, > 10 years 5\%. Levels of education consist of High school $7 \%$, Associate $33 \%$, Bachelor 57\%, Master 3\%.

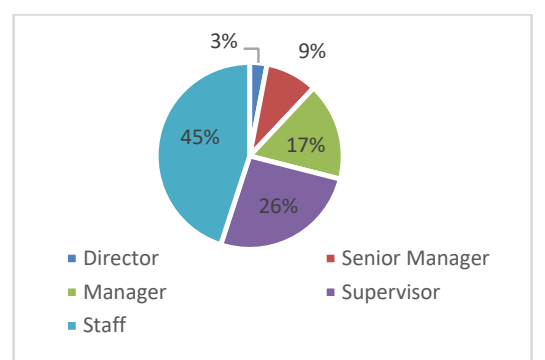

Level of seniority

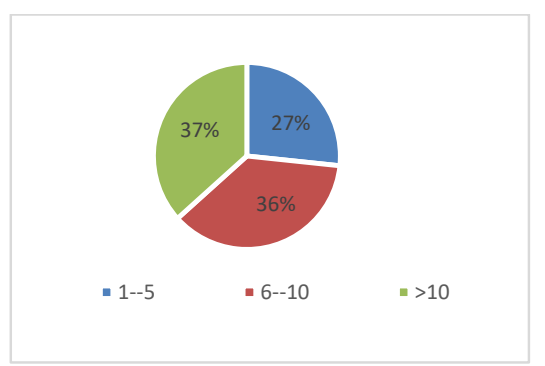

Length of work

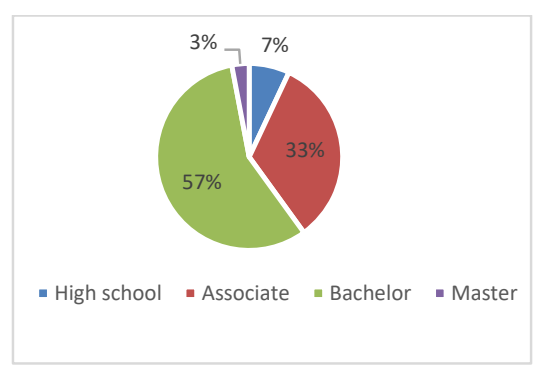

Level of education

Fig. 2. Personal characteristics of the participants

\subsection{Government regulation variables (X1)}

Based on the results of data collection through questionnaires, the variable Government regulation (X1) as one of the factors that affect Dry port Firm Performance has the following statistical processing. 
Table 1

Statistical variables of government regulation $\left(\mathrm{X}_{1}\right)$

\begin{tabular}{lll} 
& Valid & 75 \\
& Missing & 0 \\
Mean & & 38.45 \\
Std. Deviation & 4.759 \\
Minimum & 37 \\
Maximum & 59 \\
Sum & 3024 \\
\hline
\end{tabular}

\subsection{Service Stakeholder Commitment Variables $\left(X_{2}\right)$}

Based on the results of data collection through questionnaires, the variable Service Stakeholder Commitment (X2) as one of the factors that affect Dry port Firm Performance has the following statistical processing:

Table 2

Statistical Variables of Service Stakeholder Commitment $\left(\mathrm{X}_{2}\right)$

\begin{tabular}{lll}
\hline $\mathrm{N}$ & Valid & 75 \\
Mean & Missing & 0 \\
Std. Deviation & & 47.53 \\
Minimum & 11.121 \\
Maximum & 33 \\
Sum & 72 \\
\hline
\end{tabular}

\subsection{Dry port Firm Performance Variables $(Y)$}

Based on the results of data collection through questionnaires, the variable Dry port Firm Performance (Y), which is the dependent variable, has the following statistical processing:

Table 3

Statistical Variables Dry port Firm Performance (Y)

\begin{tabular}{lll}
\hline $\mathrm{N}$ & Valid & 75 \\
Mean & Missing & 0 \\
Std. Deviation & & 45.87 \\
Minimum & & 7.142 \\
Maximum & 39 & 65 \\
Sum & 3158 \\
\hline
\end{tabular}

\section{Result}

The multiple regression analysis results show a significant simultaneous influence between the Government regulation, Service Stakeholder Commitment, on Dry port Firm Performance. The F value is 21,345; the importance of $t$ count for each variable were 2.345 and 2.094. The regression coefficient is 0.165 and 0.354 . Meanwhile, adjusted R2 is 0.319 , which indicates that the two independent variables' effect on the dependent variable is $31.9 \%$. This study recommends that each independent variable support the other. The significance effect has almost the same value if the two go together and separately.

\section{Table 4}

Results of Multiple linear regression

\begin{tabular}{|c|c|c|c|c|}
\hline Variable & Sig & $t$ count & Regression coefficient & Results \\
\hline $\mathrm{X}_{1}$ to $\mathrm{Y}$ & 0,000 & 2,345 & 0,165 & Significant \\
\hline $\mathrm{X}_{2}$ to $\mathrm{Y}$ & 0,001 & 2,094 & 0,354 & Significant \\
\hline \multicolumn{5}{|c|}{ Constanta $=11,247$} \\
\hline \multicolumn{5}{|c|}{ Adjusted $\mathrm{R}^{2}=0,319$} \\
\hline \multicolumn{5}{|c|}{$\mathrm{F}$ count $=21,345$} \\
\hline \multicolumn{5}{|c|}{ Sig $=0,000$} \\
\hline
\end{tabular}

\section{Conclusion}

We have proposed a new analytical framework to study the dynamic influence of government regulation and stakeholder participation on dry port companies' performance and present empirical data to demonstrate this approach's value. We have differentiated the level of objective, current and practical social reality to show that regulation has multiple causal forces 
and produces various effects on dry port companies' performance; the rule does not only limit business activities and performance. Regulatory developments cannot reduce perceptions or regularity concerning performance. Regulation affects the performance of dry port companies, stakeholders. The effect of law largely depends on how dry port companies and the stakeholders they interact with, including actual and potential customers, suppliers, competitors, infrastructure providers, and regulatory authorities, adapt to the regulations. Stakeholder engagement shows results and implementation to achieve dry port performance, and evidence of this can found in meeting reports or minutes. It seems difficult enough, but it works very well; this is the first time they have participated in such a participatory process. The stakeholders' influence is very significant concerning the thematic scope and the different stages' expected results. Insiders are interested in new ideas but are also skeptical when potential vested interests are at stake. Stakeholder engagement with the meeting outcome was very high among those involved in presenting the dry port performance. Stakeholders can provide input for a participatory process involving them. Stakeholder engagement with the development of the process is broad but limited to the stakeholder group involved. The stakeholder engagement and co-ownership of the stakeholder process results, although the latter does not guarantee implementation. Involving marginalized groups requires a lot of capacity-building effort but greatly expands stakeholder engagement and engagement.

\section{References}

Dube, N., Van der Vaart, T., Teunter, R. H., \& Van Wassenhove, L. N. (2016). Host government impact on the logistics performance of international humanitarian organisations. Journal of Operations Management, 47, 44-57.

Giao, H., Vuong, B., \& Quan, T. (2020). The influence of website quality on consumer's e-loyalty through the mediating role of e-trust and e-satisfaction: An evidence from online shopping in Vietnam. Uncertain Supply Chain Management, 8(2), 351-370.

Grigoriou, K., \& Rothaermel, F. T. (2017). Organizing for knowledge generation: Internal knowledge networks and the contingent effect of external knowledge sourcing. Strategic Management Journal, 38(2), 395-414.

Hervás-Peralta, M., Poveda-Reyes, S., Molero, G. D., Santarremigia, F. E., \& Pastor-Ferrando, J. P. (2019). Improving the performance of dry and maritime ports by increasing knowledge about the most relevant functionalities of the Terminal Operating System (TOS). Sustainability, 11(6), 1648.

Hitt, M. A., Ireland, R. D., \& Hoskisson, R. E. (2016). Strategic management: concepts: competitiveness and globalization. Cengage Learning.

Kamil, P. A., Utaya, S., \& Utomo, D. H. (2020). Improving disaster knowledge within high school students through geographic literacy. International Journal of Disaster Risk Reduction, 43, 101411.

Khaslavskaya, A., \& Roso, V. (2020). Dry ports: research outcomes, trends, and future implications. Maritime Economics \& Logistics, 1-28.

Lamii, N., Bentaleb, F., Fri, M., Douaioui, K., Mabrouki, C., \& Semma, E. A. (2020). Systematic Review of Literature on Dry Port Concept Evolution. Transactions on Maritime Science, 9(02), 248-270.

Lantu, D. C., Triady, M. S., Utami, A. F., \& Ghazali, A. (2016). Pengembangan model peningkatan daya saing UMKM di Indonesia: Validasi kuantitatif model. The Asian Journal of Technology Management, 15(1), 77.

Novar, M. F., Ridwan, A. Y., \& Santosa, B. (2018, October). SCOR and ahp based monitoring dashboard to measure rice sourcing performance at Indonesian bureau of logistics. In 2018 12th International Conference on Telecommunication Systems, Services, and Applications (TSSA) (pp. 1-6). IEEE.

Witte, P., Wiegmans, B., Braun, C., \& Spit, T. (2016). Weakest link or strongest node? Comparing governance strategies for inland ports in transnational European corridors. Research in Transportation Business \& Management, 19, 97-105.

Rezaei, J., van Wulfften Palthe, L., Tavasszy, L., Wiegmans, B., \& van der Laan, F. (2019). Port performance measurement in the context of port choice: an MCDA approach. Management Decision, 57(2).

Simatupang, T. M., \& Sridharan, R. (2018). Complementarities in supply chain collaboration. Industrial Engineering and Management Systems, 17(1), 30-42.

Yulianti, D., Rusilowati, A., \& Nugroho, S. E. (2020, June). Student worksheets based on Science, Technology, Engineering and Mathematics (STEM) to facilitate the development of critical and creative thinking skills. In Journal of Physics: Conference Series (Vol. 1567, No. 2, p. 022068). IOP Publishing. 
(C) 2021 by the authors; licensee Growing Science, Canada. This is an open access article distributed under the terms and conditions of the Creative Commons Attribution (CC-BY) license (http://creativecommons.org/licenses/by/4.0/). 